\title{
Identification of the metal center of chlorothalonil hydrolytic dehalogenase and enhancement of catalytic efficiency by directed evolution
}

\author{
Honghong Chen, Hui Wang, Tongtong Wang, Songren Huang, Xiaoxia Zang, Shunpeng Li and \\ Jiandong Jiang*
}

Department of Microbiology, Key Lab of Microbiological Engineering of Agricultural Environment, Ministry of Agriculture, College of Life Sciences, Nanjing Agricultural University, 210095, Nanjing, Jiangsu Province, People’s Republic of China

\begin{abstract}
Chlorothalonil hydrolytic dehalogenase (Chd) is one of two reported hydrolytic dehalogenases for halogenated aromatics, and its catalysis is independent of coenzyme A and ATP. Earlier studies have established that the catalytic activity of Chd requires zinc ions. In this study, the metal center of Chd was systematically investigated. The metal content of Chd was determined by inductively coupled plasma-atomic emission spectrometry (ICP-AES), and there were 2.14 equivalents of zinc/mol of protein, indicating that Chd contains a binuclear $\left(\mathrm{Zn}^{2+}-\mathrm{Zn}^{2+}\right)$ center. It was found that other divalent cations, such as cobalt $\left(\mathrm{Co}^{2+}\right)$ and cadmium $\left(\mathrm{Cd}^{2+}\right)$, could substitute zinc $\left(\mathrm{Zn}^{2+}\right)$ leading to relative activities of $91.6 \%$ and $120.0 \%$, whereas manganese $\left(\mathrm{Mn}^{2+}\right)$ and calcium $\left(\mathrm{Ca}^{2+}\right)$ could substitute $\mathrm{Zn}^{2+}$ leading to relative activities of $29.1 \%$ and $57.0 \%$, respectively. The enzymatic properties of these different metal ion-substituted Chd variants were also compared. Error-prone PCR and DNA shuffling methods were applied to directly evolve Chd to generate variants with higher catalytic efficiencies of chlorothalonil. Enhanced Chd variants were selected based on the formation of clear haloes on Luria-Bertani plates supplemented with chlorothalonil. One variant, Q146R/N168Y/S303G, exhibited a 4.43-fold increase in catalytic efficiency, showing the potential for application in the dehalogenation and detoxification of chlorothalonil contaminated-sites.
\end{abstract}

Keywords: chlorothalonil hydrolytic dehalogenase, metallo- $\beta$-lactamase, binuclear center, metal ion substitution, directed evolution

*Correspondence to: Jiandong Jiang, Department of Microbiology, College of Life Sciences, Nanjing Agricultural University, 210095, Nanjing, Jiangsu Province, People’s Republic. of China; Email: jiang_jjd@njau.edu.cn

Received: September 9, 2015; Accepted: January 20, 2016; Published Online: April 7, 2016

Citation: Chen H, Wang H, Wang T, et al. 2016, Identification of the metal center of chlorothalonil hydrolytic dehalogenase and enhancement of catalytic efficiency by directed evolution. Applied Environmental Biotechnology, vol.1(1): 30-37.

http://dx.doi.org/10.26789/AEB.2016.01.003.

\section{Introduction}

$\mathrm{D}$ ehalogenases encoded by microorganisms play key roles in the dehalogenation and detoxification of halogenated compounds ${ }^{[1]}$. The chlorothalonil hydrolytic dehalogenase (Chd) characterized in our laboratory catalyzes a direct hydroxyl- substitution of the 4-chlorine atom of the chlorinated aromatic fungicide chlorothalonil (2,4,5,6-tetrachloroisophthalonitrile), which is the second most widely used as an agricultural fungicide in the United States ${ }^{[2,3]}$. The catalytic mechanism of Chd is different from dehalogenases for short-chain halogenated aliphatic hydrocarbons and carboxylic acids ${ }^{[4-6]}$ and also 
different from the 4-chlorobenzoyl-CoA dehalogenase, whose catalytic function is dependent on coenzyme $\mathrm{A}$ (CoA) and $\mathrm{ATP}^{[7,8]}$. To the best of our knowledge, Chd is the first reported dehalogenase belonging to the metallo- $\beta$-lactamase superfamily. Our previous studies showed that Chd contains a conserved domain of the metallo- $\beta$-lactamase superfamily. Moreover, Chd was completely inhibited by metalloprotease inhibitor 1,10-phenanthroline ( $1 \mathrm{mM})$, and the catalytic activity was recovered by the subsequent supplementation of $\mathrm{Zn}^{2+}$. All these data showed that the possession of a divalent cation is essential for Chd activity.

Metallo- $\beta$-lactamases requires a metal cofactor to be enzymatically active. In vivo, metallo- $\beta$-lactamases probably function in the $\mathrm{Zn}^{2+}$-bound form, but activity is also observed in the $\mathrm{Cd}^{2+}$ - or $\mathrm{Co}^{2+}$-bound forms of the enzyme ${ }^{[9-11]}$. Despite the existence of a pattern for binuclear zinc binding, a structure of metallo- $\beta$-lactamase containing only a single zinc ion also has been reported ${ }^{[12]}$. Whether the $\mathrm{Zn}^{2+}$ in the catalytic center of Chd can be substituted by other metal ions and whether Chd contains a mono or binuclear center remain unclear.

Directed evolution is usually used to evolve proteins with desirable properties, and it has been reported to successfully generate enzyme variants with a broader substrate range, enhanced catalytic activity, and thermostability ${ }^{[13-18]}$. Chd can only dechlorinate one of four chlorines from chlorothalonil to generate 4-hydroxy-trichloroisophthalonitrile (4-TPN-OH); therefore, the substrate range and the catalytic activity of Chd still may be improved. The potential utility of Chd would be greatly improved if its substrate range or catalytic activity could be broadened and enhanced. In this paper, the metal center of Chd was systematically investigated, including the metal ion content (binuclear or mononuclear center) and the possibility for metal ion substitutions. Error-prone PCR and DNA shuffling methods were also used to generate Chd variants with enhanced catalytic efficiency. The investigation of the metal center allows us to know much more about the catalytic mechanism of Chd, while the directed evolution of Chd may lead to potential biological solutions for efficient dehalogenation and detoxification of chlorothalonil contaminated-sites.

\section{Materials and Methods}

\subsection{Chemicals}

Chlorothalonil (99.3\% purity) was purchased from
Sigma-Aldrich (St. Louis, MO). 1,10-phenanthroline was purchased from J\&K Chemical Ltd (Beijing, China). All other reagents used in this study were of analytical reagent grade. T4 DNA ligase, deoxynucleoside triphosphates (dNTPs), and restriction enzymes were purchased from Takara Biotechnology Co. Ltd. (Dalian, China). PCR primers were synthesized by Invitrogen Biotechnology Co., Ltd. (Shanghai, China).

\subsection{Bacterial Strains}

The chlorothalonil dechlorinating strain, Pseudomonas sp. CTN-3 ${ }^{[2]}$, was stored in our lab. Escherichia coli DH5 $\alpha$ and BL21 (DE3) strains were used for genetic construction and protein expression, respectively.

\subsection{Metal Ion Content Determination}

The wild-type Chd was expressed and purified as described previously ${ }^{[2]}$. The purified Chd was first dialyzed for 24 hrs to remove non-binding metals. The dialysate used was $20 \mathrm{mM}$ Tris- $\mathrm{HCl}(\mathrm{pH} 7.9)$ and was changed several times. Then, Chd was digested with $\mathrm{HNO}_{3}$. The metal contents were determined by inductively coupled plasma-atomic emission spectrometry (ICP-AES) (Optima 2100DV, Perkin Elmer). Glassware, test tubes, and tips were pretreated by $\mathrm{HNO}_{3}$ to prevent metal ion contamination. The metal content value reported is an average of readings from two independent experiments.

\subsection{Zinc Ions Replacement}

The purified wild-type Chd was incubated in $20 \mathrm{mM}$ Tris-HCl buffer (pH 7.9) containing $10 \mathrm{mM} \mathrm{1,10-}$ phenanthroline at $4^{\circ} \mathrm{C}$ for $24 \mathrm{hrs}$, and then dialyzed against deionized water ( $\mathrm{pH} 7.0$ ) for 24 hrs to remove 1,10-phenanthroline- $\mathrm{Zn}^{2+}$ and excess 1,10-phenanthroline. The apoenzyme of Chd (apo-Chd) prepared in this manner was completely inactive. Incubation of the enzyme without 1,10 -phenanthroline was also used as the control. Different divalent metal ions $\left(\mathrm{Co}^{2+}, \mathrm{Cd}^{2+}\right.$, $\mathrm{Mn}^{2+}, \mathrm{Ca}^{2+}, \mathrm{Zn}^{2+}, \mathrm{Mg}^{2+}, \mathrm{Hg}^{2+}, \mathrm{Cu}^{2+}, \mathrm{Ni}^{2+}, \mathrm{Cr}^{2+}$, and $\mathrm{Fe}^{2+}$ ) were supplemented to apo-Chd system to a final concentration of $0.5 \mathrm{mM}$, and then the mixture was dialyzed against deionized water to remove excess metal ions. The relative activities of these metal ionsubstituted Chd were assayed to see whether these metal ions restored the catalytic activity.

\subsection{Random Mutagenesis}

A mutagenesis library was generated by error-prone 
PCR with the genomic DNA of strain CTN-3 as the template. The primer pair F1/R1 5'-ATCAGAATCCCCGCCTGGATGTTCCGG-3' (underlined, BamHI site) and 5'-CAATAAGCTTAGGCCTGGCTGCGAGAT-3' (underlined, HindIII site) was used. To obtain the desired level of mutation (2 to 3 nucleotide substitutions per $1 \mathrm{~kb}$ of gene), conditions used for error-prone PCR were optimized; the reaction mixture contained $5 \mathrm{mM} \mathrm{MgCl}, 0.2 \mathrm{mM} \mathrm{MnCl}_{2}, 0.2 \mathrm{mM}$ dATP and dGTP, $1 \mathrm{mM} \mathrm{dCTP} \mathrm{and} \mathrm{dTTP,} 25$ pmol of each oligonucleotide primer, 20 ng of template, and 2 $\mathrm{U}$ of Taq polymerase. PCR was performed for 30 cycles consisting of $94^{\circ} \mathrm{C}$ for $30 \mathrm{sec}, 56^{\circ} \mathrm{C}$ for $30 \mathrm{sec}$, and $72^{\circ} \mathrm{C}$ for $1 \mathrm{~min}$. Mutagenic PCR products were digested with BamHI and HindIII and were gel purified with a purification kit (Shanghai Genebase GeneTech Co., Ltd.). Purified PCR products were ligated with the same enzyme digested pMD-18T to generate pMD-chd. E. coli DH5a cells harboring pMD-chd were plated onto Luria-Bertani (LB) agar plates containing $100 \mu \mathrm{g} / \mathrm{ml}$ ampicillin and $50 \mu \mathrm{g} / \mathrm{ml}$ chlorothalonil for prescreening.

\subsection{DNA Shuffling}

The dechlorinating activity-improved variants from the first-round of random mutagenesis were used as templates for DNA shuffling ${ }^{[15]}$. The chd genes from different variants were equally mixed and then digested with $0.002 \mathrm{U}$ of DNase I (Fermentas MBI) at $37^{\circ} \mathrm{C}$ for $15 \mathrm{~min}$. The reaction was stopped by heating at $100^{\circ} \mathrm{C}$ for $10 \mathrm{~min}$. DNA fragments of $100-250 \mathrm{bp}$ were isolated from a $2 \%$ agarose gel with a DNA recovery kit (Shanghai Generay Biotech Co., Ltd). Approximately $0.1 \mathrm{~g}$ of the fragmented templates was mixed together and reassembled in a $25 \mu$ volume of primerless PCR by using pfu DNA polymerase (Promega). Conditions for PCR were as follows: $1 \mathrm{~min}$ at $95^{\circ} \mathrm{C}$, followed by 60 cycles of $30 \mathrm{~s}$ at $94^{\circ} \mathrm{C}, 30 \mathrm{~s}$ at $52^{\circ} \mathrm{C}$, and $30 \mathrm{~s}$ at $72^{\circ} \mathrm{C}$, followed by $2 \mathrm{~min}$ at $72^{\circ} \mathrm{C}$.

The reassembled product was diluted 10 times and used in an additional PCR amplification using the primer pair F1/R1. The 1.0-kb product was double digested with BamHI/HindIII and subcloned to the same enzymes digested pMD-18T to generate a library of Chd variants. The resulting recombinant plasmids were transformed into E. coli DH5 $\alpha$ for prescreening.

\subsection{Prescreening of Chd Variants for Enhanced Hydrolysis of Chlorothalonil}

A plate assay based on the formation of clear haloes due to chlorothalonil dechlorination was used for rapid prescreening of enhanced Chd variants. Transformants were plated onto LB agar containing $50 \mu \mathrm{g} / \mathrm{mL}$ chlorothalonil and $100 \mu \mathrm{g} / \mathrm{mL}$ ampicillin and maintained at $15^{\circ} \mathrm{C}$ for $48 \mathrm{hrs}$. Colonies with larger clear haloes were screened from those containing the wild-type Chd. These potential colonies were cultured in LB liquid medium and then dropped onto a chlorothalonil plate at the same cell concentrations for a second-round of screening. Colonies with confirmed larger haloes were selected. The chd genes in these colonies were double sequenced by Shanghai Invitrogen Biotechnology Co., Ltd, and Chd variants were further expressed and purified for enzymatic assay.

\subsection{Expression and Purification of Chd}

Plasmid pET29a(+) was used for expression of the Chd variants as an N-terminal fusion to a hexahistidine tag (His6) for easy purification. The E. coli BL21 (DE3) cells containing the recombinant Chd were cultivated in LB liquid medium containing $100 \mu \mathrm{g} / \mathrm{mL}$ kanamycin at $37^{\circ} \mathrm{C}$ with shaking at $200 \mathrm{rpm}$ for approximately 3 hrs. When the OD reached 0.5-0.8 (approximately $6-8 \mathrm{hrs}$ ), isopropyl $\beta$-D-1-thiogalactopyranoside (IPTG) was added and then the incubation system was shaken at $150 \mathrm{rpm}$ at $30^{\circ} \mathrm{C}$. Cells were harvested with continuous centrifugation $(6000 \times \mathrm{g}$ for $5 \mathrm{~min}$ ), then washed and re-suspended in Tris- $\mathrm{HCl}$ buffer (20 mM, pH 7.9) at $4^{\circ} \mathrm{C}$ and lysed by sonication on ice. All purification procedures were performed at $4^{\circ} \mathrm{C}$. Cell debris and insoluble proteins were removed by centrifugation $\left(12,000 \times \mathrm{g}\right.$ for $10 \mathrm{~min}$ at $\left.4^{\circ} \mathrm{C}\right)$. Expressed Chd was purified from the crude extract using Ni-nitrilotriacetic acid affinity chromatography as described previously ${ }^{[2]}$. The purity of Chd was determined by sodium dodecyl sulfate polyacrylamide gel electrophoresis (SDS-PAGE). Protein concentration was quantified by the Bradford method using bovine serum albumin as the standard.

\subsection{Enzyme Kinetics Study}

Standard enzyme activity assays were performed in phosphate-buffered saline (PBS, $50 \mathrm{mM}, \mathrm{pH}$ 7.0). The enzyme $(10 \mu \mathrm{L})$ was mixed with $0.2 \mathrm{mM}$ chlorothalonil in $1 \mathrm{~mL}$ of PBS, and the reaction mixture was incubated at $37^{\circ} \mathrm{C}$ for $10 \mathrm{~min}$. One unit of enzyme activity was defined as the amount of enzyme that produced $1 \mu \mathrm{mol}$ of the metabolite 4-TPN-OH per min from chlorothalonil. The concentration of 4-TPN-OH was measured by HPLC method. Similarly, the kinetic 
parameters $k$ cat and $K_{m}$, optimum $\mathrm{pH}$, $\mathrm{pH}$ stability, optimum temperature, and thermostability were determined as described previously ${ }^{[2]}$.

The $\mathrm{pH}$ range of Chd and its variants was determined by incubating $10 \mu \mathrm{L}$ enzyme with $0.2 \mathrm{mM}$ chlorothalonil in $1 \mathrm{~mL}$ reaction buffer at $50^{\circ} \mathrm{C}$ for 30 sec at $\mathrm{pH}$ values ranging from 4.0 to 10.0 . For $\mathrm{pH}$ stability determination, enzyme was pre-incubated at different $\mathrm{pH}$ values (ranging from 4.0 to 10.0 ) at $50^{\circ} \mathrm{C}$ for $10 \mathrm{~min}$, and then the remaining activity was assayed as described above. The reaction buffers were Citric acid-NaOH buffer (pH 4.0-5.0), PBS (pH 6.0-8.0), Tris-HCl buffer (pH 9.0), and Glycin-NaOH buffer ( $\mathrm{pH} 10.0$ ), respectively. The optimal temperature was determined analogously by incubating $10 \mu \mathrm{l}$ enzyme with $0.2 \mathrm{mM}$ chlorothalonil in $1 \mathrm{~mL}$ PBS (50 $\mathrm{mM}, \mathrm{pH}$ 7.0) for $10 \mathrm{~min}$ at different temperatures ranging from $4^{\circ} \mathrm{C}$ to $70^{\circ} \mathrm{C}$. To determine the thermo-stability, enzyme was pre-incubated in a water bath at different temperatures $\left(4-70^{\circ} \mathrm{C}\right)$ for $1 \mathrm{hr}$ and then the remaining activity was determined.

\section{Results}

\subsection{The Zinc Ion Content of Chd}

The native Chd expressed in E. coli BL21 (DE3) was purified from the crude extract using Ni-nitrilotriacetic acid affinity chromatography. The SDS-PAGE analysis of the purified Chd yielded a single band with a molecular weight of approximately $36 \mathrm{kDa}$, showing that Chd was sufficiently purified. The ICP-AES analysis showed that there were $2.283 \mu \mathrm{g}$ zinc ions in $605.625 \mu \mathrm{g}$ purified Chd. Because Chd is a monomer, the results showed that the ion content is approximately $2.14 \mathrm{~mol}$ of $\mathrm{zinc} / \mathrm{mol}$ of protein, indicating that Chd has a binuclear center (each Chd molecule contains two zinc ions).

\subsection{Substitution of Zinc Ions with Other Metal Ions}

The apo-Chd was prepared by the metal-ion chelator 1,10-phenanthroline and was completely inactive. In addition to the $\mathrm{Zn}^{2+}$, the catalytic activity of apo-Chd was fully or partially recovered by the subsequent supplementation of $\mathrm{Co}^{2+}, \mathrm{Cd}^{2+}, \mathrm{Mn}^{2+}$, or $\mathrm{Ca}^{2+}$ (Table 1 and Figure 1). However, subsequent supplementation of $\mathrm{Cu}^{2+}, \mathrm{Ni}^{2+}, \mathrm{Mg}^{2+}, \mathrm{Hg}^{2+}, \mathrm{Cr}^{2+}$, or $\mathrm{Fe}^{2+}$ could not recover the catalytic activity. It is interesting that the $\mathrm{Co}^{2+}$-substituted Chd had the highest specific activity $(20.8 \pm 2.9 \mathrm{U} / \mu \mathrm{g})$ (Figure 1) and catalytic efficiency $\left(1.142 \mu \mathrm{M}^{-1} \mathrm{~s}^{-1}\right.$ ) (Table 1), indicating that cobalt may
Table 1. The kinetic parameters for hydrolysis of chlorothalonil by different metal ion-substituted Chd

\begin{tabular}{cccr}
\hline Metal ion & $k_{\text {cat }} / K_{m}\left(\mu \mathrm{M}^{-1} \mathrm{~s}^{-1}\right)$ & $K_{m}(\mu \mathrm{M})$ & $k_{\text {cat }}\left(\mathrm{s}^{-1}\right)$ \\
\hline $\mathrm{Zn}^{2+}$ & 0.967 & $154.4 \pm 4.2$ & $149.3 \pm 3.1$ \\
$\mathrm{Co}^{2+}$ & 1.142 & $134.4 \pm 3.6$ & $153.5 \pm 2.9$ \\
$\mathrm{Cd}^{2+}$ & 0.554 & $157.8 \pm 3.9$ & $87.4 \pm 2.7$ \\
$\mathrm{Mn}^{2+}$ & 0.375 & $168.3 \pm 2.1$ & $63.1 \pm 3.5$ \\
$\mathrm{Ca}^{2+}$ & 0.279 & $171.3 \pm 5.1$ & $47.8 \pm 1.1$ \\
\hline
\end{tabular}

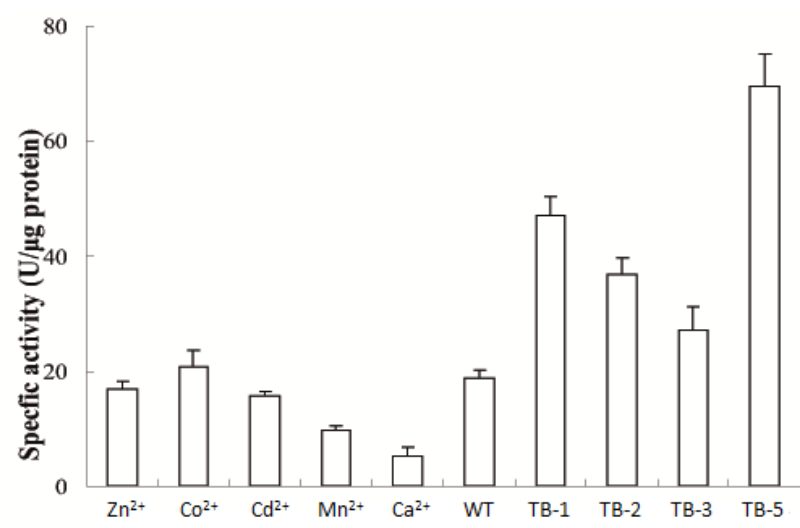

Figure 1. Comparison of the specific activities of different metal ion-substituted Chd and Chd variants. WT, wide type; TB-1, L109H/S303G; TB-2, Q146R/N168Y; TB-3, L243E/ E249D; TB-5, Q146R/N168Y/S303G.

also be an excellent metal center for Chd.

\subsection{Enzymatic Properties of the Different Metal Ion-substituted Chd}

Because the enzymatic activity of $\mathrm{Ca}^{2+}$-substituted Chd was relatively low, only $\mathrm{Co}^{2+}-, \mathrm{Cd}^{2+}$-, and $\mathrm{Mn}^{2+}$ substituted Chd were selected for comparison to the $\mathrm{Zn}^{2+}$-substituted Chd. The optimum temperature for catalysis by $\mathrm{Zn}^{2+}$-substituted Chd was found to be $50^{\circ} \mathrm{C}$, which agrees with a previous study ${ }^{[2]}$. Interestingly, the optimum temperature decreased to $40^{\circ} \mathrm{C}$ when $\mathrm{Zn}^{2+}$ was replaced by $\mathrm{Co}^{2+}$ or $\mathrm{Cd}^{2+}$ (Figure 2). The relative activity of $\mathrm{Co}^{2+}$-substituted Chd at $40^{\circ} \mathrm{C}$ was about 1.23-fold greater than that of the $\mathrm{Zn}^{2+}$ substituted Chd at its optimum temperature. However, the optimum temperature remained unchanged when $\mathrm{Mn}^{2+}$ replaced $\mathrm{Zn}^{2+}$, though the relative activity was only $57.0 \%$ of the $\mathrm{Zn}^{2+}$-substituted Chd.

The $\mathrm{Zn}^{2+}$-substituted Chd was relatively stable at $25-50^{\circ} \mathrm{C}$, and it lost less than $20 \%$ of its activity when the temperature was increased from $25^{\circ} \mathrm{C}$ to $50^{\circ} \mathrm{C}$ (Figure 3). However, the $\mathrm{Co}^{2+}$ - and $\mathrm{Mn}^{2+}$-substituted Chd were unstable above $40^{\circ} \mathrm{C}$, and the $\mathrm{Cd}^{2+}$-substituted Chd was unstable at $50^{\circ} \mathrm{C}$. The $\mathrm{Co}^{2+}$ - and $\mathrm{Mn}^{2+}$ - 


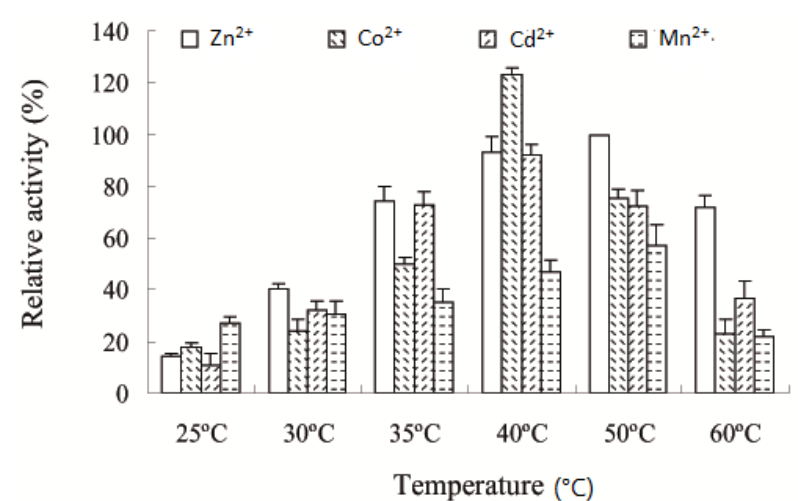

Figure 2. The optimum temperature of different metal ion-substituted Chd. The relative activity of $\mathrm{Zn}^{2+}$-substituted Chd at $50^{\circ} \mathrm{C}$ was taken as $100 \%$.

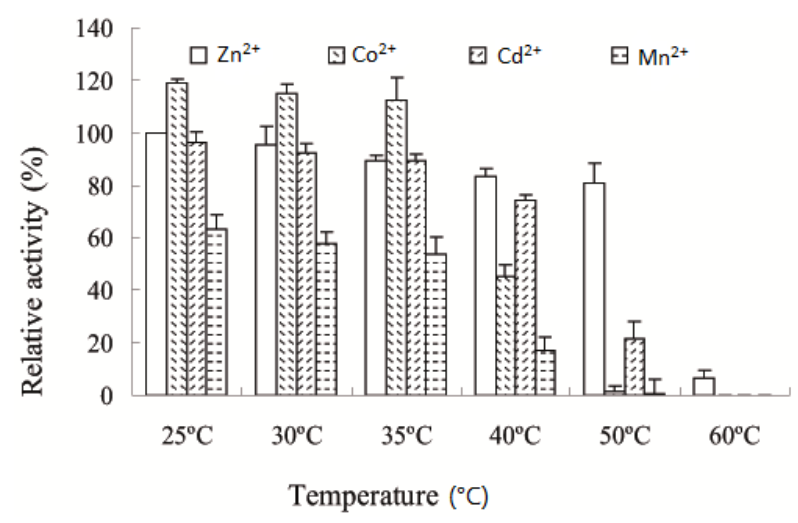

Figure 3. The thermostability of different metal ion-substituted Chd. The relative activity of $\mathrm{Zn}^{2+}$-substituted $\mathrm{Chd}$ at $25^{\circ} \mathrm{C}$ was taken as $100 \%$.

substituted Chd lost more than $60 \%$ of their activities when the temperature was increased from $25^{\circ} \mathrm{C}$ to $40^{\circ} \mathrm{C}$, and the $\mathrm{Cd}^{2+}$-substituted Chd lost more than $70 \%$ activity when the temperature was increased to $50^{\circ} \mathrm{C}$.

The optimum $\mathrm{pH}$ for catalysis was increased from 7 to 8 when $\mathrm{Zn}^{2+}$ was substituted by $\mathrm{Co}^{2+}$. The relative activity of $\mathrm{Co}^{2+}$-substituted Chd at $\mathrm{pH} 8$ was about 1.22-fold greater than that of $\mathrm{Zn}^{2+}$-substituted Chd at its optimum $\mathrm{pH}$ (Figure 4). The optimum $\mathrm{pH}$ remained nearly unchanged when $\mathrm{Zn}^{2+}$ was substituted by $\mathrm{Cd}^{2+}$ or $\mathrm{Mn}^{2+}$.

All of the metal ion-substituted Chd were fairly stable at pH 6-9 and retained more than $65 \%$ of their original activities after pre-incubation at that $\mathrm{pH}$ range for 10 min (Figure 5). It seems that metal ion substitution would not significantly change the $\mathrm{pH}$ stability.

\subsection{Directed Evolution of Chd}

Error-prone PCR was first used to evolve Chd. A mutagenic library (about 3,000 clones) was constructed with a mutation rate of between 2 and 3 mutations per

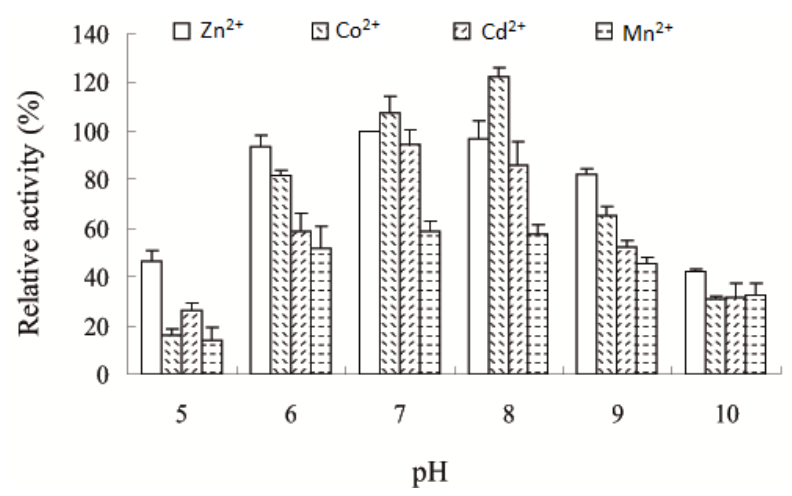

Figure 4. The optimum $\mathrm{pH}$ of different metal ion-substituted Chd. The relative activity of $\mathrm{Zn}^{2+}$-substituted Chd at $\mathrm{pH} 7$ was taken as $100 \%$.

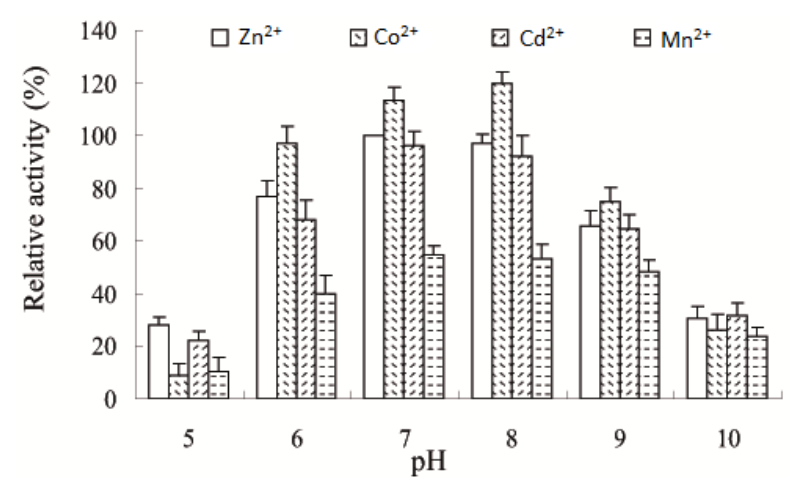

Figure 5. The $\mathrm{pH}$ stability of different metal ion-substituted Chd. The relative activity of $\mathrm{Zn}^{2+}$-substituted Chd incubated at $\mathrm{pH} 7$ was taken as $100 \%$.

1,000 bp. Three variants, TB-1 (L109H/S303G), TB-2 (Q146R/N168Y), and TB-3 (L243E/E249D), with large clear haloes as compared to those of the wild-type Chd were screened (Figure 6). It was found that these Chd variants exhibited a 1.44- to 2.51-fold increase in specific activity, and $k_{\text {cat }}$ values increased up to 2.95-fold. There was also a modest increase in $K_{m}$ values (Table 2). The overall improvement in the catalytic efficiency $\left(k_{c a t} / K_{m}\right)$ was in line with the improvement in specific activity (Table 2; Figure 1 ).

The chd genes from the above variants were used as templates for further DNA shuffling. One variant, TB-5

Table 2. Kinetic parameters for hydrolysis of chlorothalonil by wild-type Chd and its variants

\begin{tabular}{lccc}
\hline & $k_{\text {cat }} / K_{m}\left(\mu \mathrm{M}^{-1} \mathrm{~s}^{-1}\right)$ & $K_{m}(\mu \mathrm{M})$ & $k_{\text {cat }}\left(\mathrm{s}^{-1}\right)$ \\
\hline Wild-type & 0.986 & $153.7 \pm 3.8$ & $151.5 \pm 4.6$ \\
L109H/S303G & 2.77 & $161.1 \pm 2.7$ & $446.2 \pm 9.4$ \\
Q146R/N168Y & 2.01 & $157.9 \pm 2.2$ & $317.5 \pm 6.2$ \\
L243E/E249D & 1.29 & $224.3 \pm 4.9$ & $289.3 \pm 5.1$ \\
Q146R/N168Y/S303G & 4.37 & $126.3 \pm 6.8$ & $551.8 \pm 11.2$ \\
\hline
\end{tabular}


(Q146R/N168Y/S303G), with a large clear halo on the chlorothalonil agar was selected (Figure 6), which is the combination of the mutations from variants L109H/ S303G and Q146R/N168Y. The variant Q146R/ N168Y/S303G had a 3.70-fold increase in specific activity as compared to the wild-type Chd. The variant had a 3.64-fold increase in $k_{\text {cat }}$ value and a modest decrease in $K_{m}$ with a 4.43-fold increase in catalytic efficiency $\left(4.37 \mu \mathrm{M}^{-1} \mathrm{~s}^{-1}\right)$ (Table 2), indicating that the variant Chd had a very good affinity for the substrate chlorothalonil.

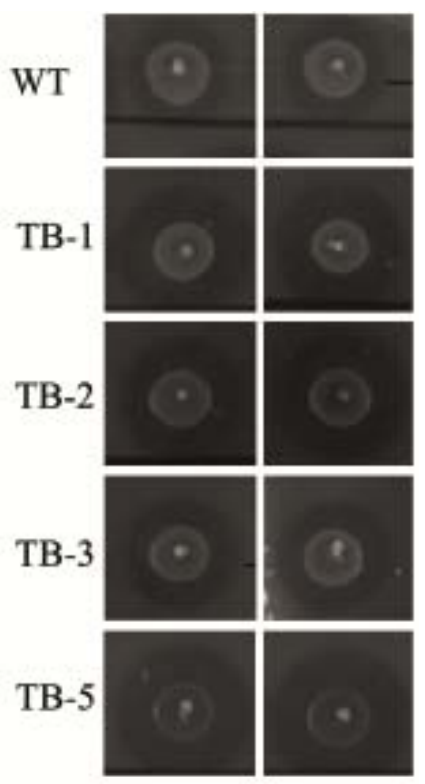

Figure 6. Clear halos formed on a plate supplemented with 50 $\mu \mathrm{g} / \mathrm{ml}$ chlorothalonil by wild-type Chd and Chd variants at 48 hrs. Cell concentrations dropped onto the plate were the same. WT, wide type; TB-1, L109H/S303G; TB-2, Q146R/N168Y; TB-3, L243E/E249D; TB-5, Q146R/N168Y/S303G.

\section{Discussion}

$\beta$-Lactamases have been grouped into four classes (A-D) according to sequence homology ${ }^{[19]}$. Class A, $\mathrm{C}$, and $\mathrm{D}$ enzymes use an active site serine residue as a nucleophile, whereas class B lactamases (generically termed metallo- $\beta$-lactamases) employ a metal cofactor to be enzymatically active. Zinc clusters have been observed in the active sites of many enzymes ${ }^{[20]}$. Seven structures that contain at least two zinc ions have been examined: alkaline phosphatase ${ }^{[21]}$, phosphotriesterase ${ }^{[22]}$, Klenow fragment of DNA polymerase $\mathrm{I}^{[23]}$, P1 nuclease ${ }^{[24]}$, phospholipase $\mathrm{C}^{[25]}$, aminopeptidase $^{[26]}$, and leucine aminopeptidase ${ }^{[27]}$. However, the enzyme from Bacillus cereus functioned reasonably well with only one bound zinc ion ${ }^{[28]}$. In our study,
ICP-AES analysis reached a value of 2.14 equivalents of zinc/mol of protein, showing that Chd contains a binuclear $\left(\mathrm{Zn}^{2+}-\mathrm{Zn}^{2+}\right)$ center. Site-directed mutations of the predicted ligand binding sites of the two zinc ions in Chd resulted in complete loss of catalytic activity, also confirming that each Chd molecule has two zinc ions (data not shown).

It was reported that metallo- $\beta$-lactamases can also contain other metal ions for catalytic activity, such as cadmium, cobalt, and manganese. The crystal structure of a $\mathrm{Cd}^{2+}$-bound metallo- $\beta$-lactamase from $\mathrm{Bac}$ teroides fragilis showed that the $\mathrm{Cd}^{2+}$-bound enzyme exhibited the same active-site architecture as that of the $\mathrm{Zn}^{2+}$-bound enzyme, consistent with the fact that both forms were enzymatically active ${ }^{[29]}$. In our study, the activity of apo-Chd (devoid of $\mathrm{Zn}^{2+}$ ) could be recovered by subsequent addition of $\mathrm{Co}^{2+}, \mathrm{Cd}^{2+}, \mathrm{Mn}^{2+}$, or $\mathrm{Ca}^{2+}$, indicating that these divalent metal ions could also act as the metal center. Different divalent metal ion-substituted Chd exhibited different enzymatic properties, such as different optimum temperatures, thermostability, and optimum $\mathrm{pH}$, showing that a different metal ion in the catalytic center might affect enzymatic properties significantly. It was interesting that $\mathrm{Co}^{2+}$-substituted Chd had a higher specific activity than the $\mathrm{Zn}^{2+}$-substituted Chd. However, thermostability results indicated that $\mathrm{Zn}^{2+}$ might be the natural metal center of Chd. This investigation of the metal center of Chd allows us to know much more about the catalytic mechanism of the first dehalogenase belonging to the metallo- $\beta$-lactamase superfamily. From the results, we can see that Chd also requires a binuclear metal center to be enzymatically active and the natural $\mathrm{Zn}^{2+}$ in the catalytic center could also be substituted by other divalent cations, though its enzymatic property was affected.

Directed evolution represents a powerful and simple method to create novel biocatalysts with dramatically improved properties ${ }^{[30]}$. Error-prone PCR, cassette mutagenesis, and DNA shuffling are commonly utilized to tailor enzymes for specific applications ${ }^{[31]}$. Because the crystal structure of Chd has not been elaborated and is dissimilar to other proteins, the method of rational design by site-directed mutagenesis based on X-ray crystallography data is not feasible. In this study, we found combination of random mutagenesis and DNA shuffling to be an effective and easy way to evolve Chd. The presence of Q146R, N168Y, and S303G mutations appears to be the most beneficial, as the L109H/S303G, Q146R/N168Y, and Q146R/N168Y/ 
S303G variants carrying some or all of these mutations exhibited 2.10- to 3.64-fold increases in $k_{c a t}$ (Table 2), indicating that these mutations may help to increase the overall hydrolytic rate through elevation of $k_{\text {cat }}$. Variant Q146R/N168Y/S303G, displaying a 4.43-fold increase in catalytic efficiency, also had a modest decrease in $K_{m}$, showing an increase in binding affinity. Mutations L243E and E249D in variant L243E/E249D showed a 1.91-fold increase in $k_{\text {cat }}$ but also an increase in $K_{m}$ value (1.46-fold). However, the mechanisms underlying the effect of mutations on catalytic activity are unclear. Unlike the directed mutation of the active-site residues, our directed evolution makes some substitutions that are away from the active sites. Though only a few substitutions were made, the improvement in catalytic efficiency by increasing the hydrolytic rate or improving the affinity with the substrate was obvious. This result indicates that our system functioned effectively in the directed evolution of Chd, which has great potential for the dehalogenation and detoxification of chlorothalonil contaminated-sites.

\section{Author Contributions}

Conceived and designed the research: HC SL JJ; performed the experiments: HC HW TW SH; analyzed the data: HC SL JJ; contributed reagents/materials/analysis tools: SL JJ; wrote the paper: HC JJ.

\section{Conflict of Interest and Funding}

This work was supported by grants the Outstanding Youth Foundation of Jiangsu Province (BK20130029), the Program for New Century Excellent Talents in University (NCET-12-0892), and the Fundamental Research Funds for the Central Universities (KYZ201422).

\section{References}

1. Van Pee K and Unversucht S, 2003, Biological dehalogenation and halogenation reactions. Chemosphere, vol.52(2): 299-312.

http://dx.doi.org/10.1016/S0045-6535(03)00204-2.

2. Wang G, Li R, Li S, et al. 2010, A novel hydrolytic dehalogenase for the chlorinated aromatic compound chlorothalonil. Journal of Bacteriology, vol.192(11): 27372745. http://dx.doi.org/10.1128/JB.01547-09.

3. Cox C, 1997, Chlorothalonil. Journal of Pesticide Reform, vol.17(4): 14-20.

4. Verschueren K H G, Seljee F, Rozeboom H J, et al. 1993, Crystallographic analysis of the catalytic mechan- ism of haloalkane dehalogenase. Nature, vol.363(6431): 693-698.

5. Newman J, Peat T S, Richard R, et al. 1999, Haloalkane dehalogenase: structure of a Rhodococcus enzyme. Biochemistry, vol.38(49): 16105-16114.

6. Marek J, Vevodova J, Kuta-Smatanova I, et al. 2000, Crystal structure of the haloalkane dehalogenase from Sphingomonas paucimobilis UT26. Biochemistry, vol.39(46): 14082-6.

7. Schmitz A, Gartemann K, Fiedler J, et al. 1992, Cloning and sequence analysis of genes for dehalogenation of 4-chlorobenzoate from Arthrobacter sp. strain SU. Applied Environmental Microbiology, vol.58: 4068-4071.

8. Scholten J D, Chang K H, Babbit P C, et al. 1991, Novel enzymic hydrolytic dehalogenation of a chlorinated aromatic. Science, vol.253: 182-185.

http://dx.doi.org/10.1126/science.1853203.

9. Bandoh K, Muto Y, Watanabe K, et al. 1991, Biochemical properties and purification of metallo- $\beta$-lactamase from Bacteroides fragilis. Antimicrobial Agents and Chemotherapy, vol.35(2): 371-372.

10. Yang Y, Rasmussen B A and Bush K, 1992, Biochemical characterization of the metallo-b-lactamase CcrA from Bacteroides fragilis TAL3636. Antimicrobial Agents and Chemotherapy, vol.36(5): 1155-1157.

11. Zang T M, Hollman D A, Crawford P A, et al. 2001, Arabidopsis glyoxalase II contains a zinc/iron binuclear metal center that is essential for substrate binding and catalysis. The Journal of Biological Chemistry, vol.276: 4788-4795. http://dx.doi.org/10.1074/jbc.M005090200.

12. Moran-Barrio J, Gonzalez J M, Lisa M N, et al. 2007, The metallo- $\beta$-lactamase GOB is a mono-Zn(II) enzyme with a novel active site. The Journal of Biological Chemistry, vol.282: 18286-18293.

http://dx.doi.org/10.1074/jbc.M700467200.

13. DiSioudi B, Miller C, Lai K, et al. 1999, Rational design of organophosphorus hydrolase for altered substrate specificities. Chemico Biological Interactions, vol.119120: 211-223.

http://dx.doi.org/10.1016/S0009-2797(99)00030-7.

14. Wu F, Li W S, Chen-Goodspeed M, et al. 2000, Rationally engineered mutants of phosphotriesterase for preparative scale isolation of chiral organophosphates. Journal of the American Chemical Society, vol.122(41): 10206-10207. http://dx.doi.org/10.1021/ja002546r.

15. Mee-Hie C C, Mulchandani A and Chen W, 2004, Altering the substrate specificity of organophosphorus hydrolase for enhanced hydrolysis of chlorpyrifos. Applied and Environmental Microbiology, vol.70(8): 4681-4685. http://dx.doi.org/10.1128/AEM.70.8.4681-4685.2004.

16. Romero P A and Arnold F H, 2009, Exploring protein fitness landscapes by directed evolution. Nature Reviews 
Molecular Cell Biology, vol.10: 866-876.

http://dx.doi.org/10.1038/nrm2805.

17. Fang Y, Lu Y, Lv F, et al. 2009, Improvement of alkaline lipase from Proteus vulgaris T6 by directed evolution. Enzyme and Microbial Technology, vol.44(2): $84-88$.

http://dx.doi.org/10.1016/j.enzmictec.2008.10.018.

18. Schreiner U, Hecher B, Obrowsky S, et al. 2010, Directed evolution of Alcaligenes faecalis nitrilase. Enzyme and Microbial Technology, vol.47(4): 140-146. http://dx.doi.org/10.1016/j.enzmictec.2010.05.012.

19. Hall B G, Salipante S J and Barlow M, 2003, The metallo- $\beta$-lactamases fall into two distinct phylogenetic groups. Journal of Molecular Evolution, vol.57: 249-254. http://dx.doi.org/10.1007/s00239-003-2471-0.

20. Vallee B L and Auld D S, 1993, New perspective on zinc biochemistry: cocatalytic sites in multi-zinc enzymes. Biochemistry, vol.32(26): 6493-6500. http://dx.doi.org/10.1021/bi00077a001.

21. Kim E E and Wyckoff H W J, 1991, Reaction mechanism of alkaline phosphatase based on crystal structures: two-metal ion catalysis. Journal of Molecular Biology, vol.218(2): 449-464. http://dx.doi.org/10.1016/0022-2836(91)90724-K.

22. Benning M M, Kuo J M, Raushel F M, et al. 1995, Three-dimensional structure of the binuclear metal center of phosphotriesterase. Biochemistry, vol.34(25): 79737978. http://dx.doi.org/10.1021/bi00025a002.

23. Beese L R and Steitz T A, 1991, Structural basis for the 3'-5' exonuclease activity of Escherichia coli DNA polymerase I: a two metal ion mechanism. The Embo Journal, vol.10(1): 25-33.
24. Volveda A, Lahm A, Sakiyama F, et al. 1991, Crystal structure of Penicillium citrinum P1 nuclease at $2.8 \AA$ resolution. The Embo Journal, vol.10(7): 1607-1618.

25. Hough E, Hansen L K, Birknes B, et al. 1989, Highresolution (1.5 $\AA$ ) crystal structure of phospholipase C from Bacillus cereus. Nature, vol.338: 357-360. http://dx.doi.org/10.1038/338357a0.

26. Chervier B, Schalk C, D’Orchymony H, et al. 1994, Crystal structure of Aeromonas proteolytica aminopeptidase: a prototypical member of the co-catalytic zinc enzyme family. Structure, vol.2(4): 283-291. http://dx.doi.org/10.1016/S0969-2126(00)00030-7.

27. Burley S K, David P R, Sweet R M, et al. 1992, Structure determination and refinement of bovine lens leucine aminopeptidase and its complex with bestatin. Journal of Molecular Biology, vol.224(1): 113-140. http://dx.doi.org/10.1016/0022-2836(92)90580-D.

28. Davies R B and Abraham E P, 1974, Metal cofactor requirements of $\beta$-lactamase II. Biochemical Journal, vol.143(1): 129-135. http://dx.doi.org/10.1042/bj1430129.

29. Nestor O C, Beth A R, Karen B, et al. 1997, Crystal structures of the cadmium- and mercury-substituted metallo- $\beta$-lactamase from Bacteroides fragilis. Protein Science, vol.6(12): 2671-2676. http://dx.doi.org/10.1002/pro.5560061225.

30. Kaur J and Sharma R, 2006, Directed evolution: an approach to engineer enzymes. Critical Reviews in Biotechnology, vol.26(3): 165-199. http://dx.doi.org/10.1080/07388550600851423.

31. Joel R C and Ana L F, 2003, Directed evolution of industrial enzymes: an update. Current Opinion in Biotechnology, vol.14(4): 438-443. http://dx.doi.org/10.1016/S0958-1669(03)00099-5. 